International Journal of Agriculture, Environment and Bioresearch

Vol. 06, No. 04; 2021

ISSN: $2456-8643$

\title{
PREVAILING TEMPERATURES, COLD AND HEAT UNITS IN THE YAQUI AND MAYO VALLEYS, MEXICO, DURING THE 2019-2020 WHEAT SEASON
}

\author{
TORRES-CRUZ Maria Monserrat, FUENTES-DAVILA Guillermo and FELIX-VALENCIA Pedro \\ INIFAP, CAMPO EXPERIMENTAL VALLE DEL YAQUI \\ Apdo. Postal 155, km 12 Norman E. Borlaug, entre 800 y 900, Valle del Yaqui, Cd. Obregón, Sonora, México CP \\ 85000 \\ https://doi.org/10.35410/IJAEB.2021.5647
}

\begin{abstract}
Development of the wheat plant is influenced by sowing date, irrigation, soil type, pest and weed control, but also by weather factors. The objective was to analyze the temperatures that prevailed in the Yaqui and Mayo Valleys during the 2019-2020 wheat season. Temperature data were obtained from the automated meteorological station network in Sonora state comprising 22 stations in the Yaqui Valley and 13 in the Mayo Valley. The data were collected on a 10 minute frequency, every hour, and daily. The average of each weather station was calculated, taking into consideration the maximum and minimum temperature, the cold units and the heat units for each season. The data were captured in excel with the daily-hourly records from all the stations. During the wheat season, the temperature ranged from $1.4^{\circ} \mathrm{C}$ to $35.6^{\circ} \mathrm{C}$ with an average of $17.8^{\circ} \mathrm{C} ; 385$ and 439 cold units were recorded in the Yaqui and Mayo Valleys, respectively. Most of the weather stations in the Mayo Valley had a similar pattern of cold unit ocurrence which were around 400, with the exception of Capetamaya which registered more than 700. In the Yaqui Valley, there were six weather stations that recorded around 400 cold units, five with more than 500, and only one with more than 600 cold units.
\end{abstract}

Keywords: Temperature, cold units, wheat, crop season 2019-2020, Yaqui Valley, Mayo Valley, Mexico.

\section{INTRODUCTION}

The state of Sonora is the leader in wheat production in Mexico, representing $51.7 \%$ of the national production. Climatic conditions favor wheat production in Sonora, particularly in the southern part of the state in the Yaqui Valley and to a lesser extent in the Mayo Valley (Márquez Berber et al., 2014). Average grain yield in the 2019-2020 crop season was $6.66 \mathrm{t} \mathrm{ha}^{-1}$ from 230,087.29 ha; 151, 122 ha were from the District of Rural Development (DDR) 148-Cajeme (Yaqui Valley) and 62,416.31 ha from the DDR-149-Navojoa, for a total of 213,538.31 ha for this region of the state (SIAP, 2021). The Yaqui Valley is one of the most important areas for agricultural production in Mexico $\left(27^{\circ} \mathrm{N}, 110^{\circ} \mathrm{W}\right)$; the climate in this valley is semi-arid, with an average annual precipitation of $317 \mathrm{~mm}$ falling mainly between June and September, and the average temperature during the wheat season (fall-winter) is $21^{\circ} \mathrm{C}$ and $30^{\circ} \mathrm{C}$ during the springsummer season (Parra-Cota et al., 2018). Similarly, the Mayo Valley is located at the extreme southern region of Sonora, with a very warm and arid climate with an annual average temperature of $23-27^{\circ} \mathrm{C}$, maximum of $43-48^{\circ} \mathrm{C}$ during June, July, and August, and minimum of 
$3.5-4^{\circ} \mathrm{C}$ in December and January. The annual average rainfall varies from 200 to $400 \mathrm{~mm}$ which is concentrated $(70 \%)$ during July to September (Padilla Valenzuela et al., 2008). Both valleys are regions where climatic conditions are different, as it was shown in 1991, when the presence of karnal bunt was greater in the Mayo than in the Yaqui Valley (Lira, 1992). A similar situation occurs with the presence and development of stripe stripe (Fuentes-Dávila et al., 2019), leaf rust (Singh et al., 2004), and spot blotch according to the reports by the local plant health authorities. The wheat growing season (November-April) is characteristically dry, and farmers typically apply 3-4 complementary irrigations throughout the crop season in the Yaqui Valley, while in the Mayo Valley farmers generally apply 2 due to the shortage of water in that region. According to Félix-Valencia et al. (2009), wheat grain yield is determined by several factors like sowing date, timely and enough irrigations, nutritional deficiencies, salinity, soil type, timely control of pest and diseases. However, the development of wheat is influenced by environmental factors like air temperature and photoperiod, which impact to a greater or lesser extent the annual variations of grain yield. Temperature is the weather factor most related to crops annual productivity (Félix-Valencia et al., 2009), which also controls the rate of development of many organisms that require the accumulation of a certain amount of heat, in order to go from one phase to the another during the agricultural cycle (Soto et al., 2009).

The knowledge about temperature variation help farmers in the adaptation and mitigation decisions, among them, the use of specific technologies in order to increase productivity and to obtain the maximum use of environmental factors in a given crop season (Félix-Valencia et al., 2009). In the case of wheat, all phenological stages are sensitive to the oscillation of air temperature; high temperatures favor a greater metabolic activity of the plant, as well as an acceleration of the physiologic processes that determine its growth and development (Moreno Dena et al., 2018). On the contrary, wheat requires the accumulation of cold units, to prolong its biological cycle, and generally this renders greater grain yield (Félix-Valencia et al., 2009). Since the temperature has a great impact on the development of the wheat plant, the objective of this work was to analyze the temperature (minimum, maximum, and number of cold units) that prevailed during the 2019-2020 wheat season in the Yaqui and Mayo Valleys.

\section{MATERIALS AND METHODS}

Temperature data were obtained from the automated meteorological station network in Sonora (REMAS, 2021) comprising 22 stations in the Yaqui Valley and 13 stations in the Mayo Valley (Fig. 1). The digital memory of the meteorological station records readings every $10 \mathrm{~min}$ and provides integrated data per hour and daily. The data set comprises the crop season fall-winter 2019-2020, from November 15 to April 30. A cold unit was considered as one hour recorded by a given weather station with a temperature below $10^{\circ} \mathrm{C}$, while a heat unit was considered as one hour recorded by a given weather station with a temperature above $30^{\circ} \mathrm{C}$ 


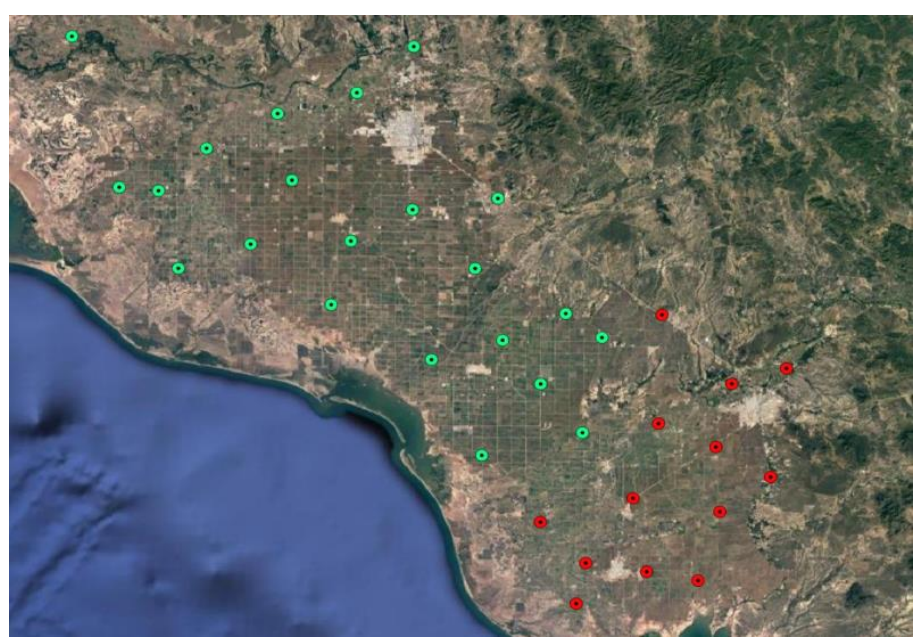

Figure 1. Location of the weather stations in the Yaqui and Mayo Valleys.

(Félix-Valencia et al., 2009). The average of each weather station was calculated, taking into consideration the maximum and minimum temperature, the cold and heat units. The data were captured in excel with the daily-hourly records from all the stations; the average hourly was calculated, so that it could be determined if cold or heat units occurred on given day in the valleys. From the same data base, it was calculated the cold and heat units for each weather station, and graphics were built with the information obtained.

\section{RESULTS AND DISCUSSION}

During this crop season, in the Yaqui Valley the temperature ranged from $1.471^{\circ} \mathrm{C}$ to $35.66^{\circ} \mathrm{C}$ with an average of $17.67^{\circ} \mathrm{C}$ (Fig. 2A), while in the Mayo Valley the range was $1.4^{\circ} \mathrm{C}$ to $35.50^{\circ} \mathrm{C}$ with an average of $17.87^{\circ} \mathrm{C}$ (Fig. 2B). An average of 385 cold units were recorded in the Yaqui Valley and 439 in the Mayo Valley.
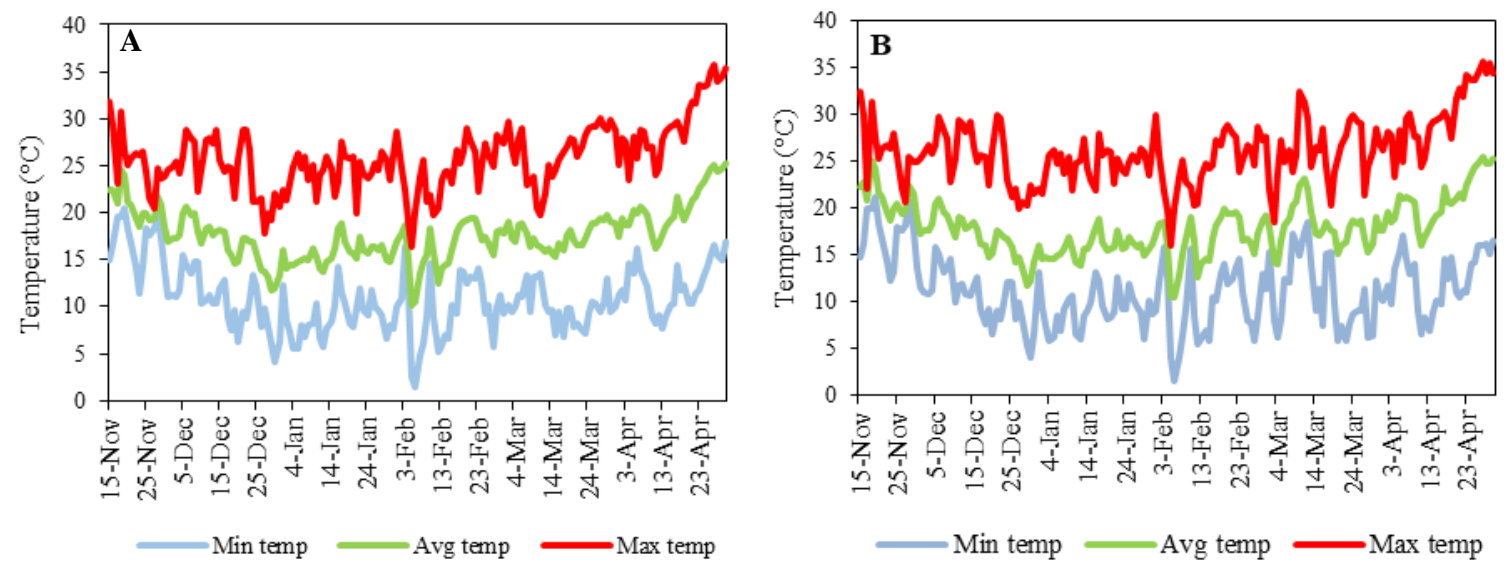
Figure 2. Minimum, maximum, and average temperature that prevailed during the wheat season 2019-2020 in the Yaqui (A) and Mayo (B) Valleys.

The occurrence of cold units in both valleys initiated on week 5 (December 13 to 19). Weeks 7 and 8 (December 27 to January 2 and January 3 to 9, respectively) had the highest number of cold units in both valleys, with a total of 46 and 44 each in the Yaqui Valley, and 43 each in the Mayo Valley (Fig. 3).

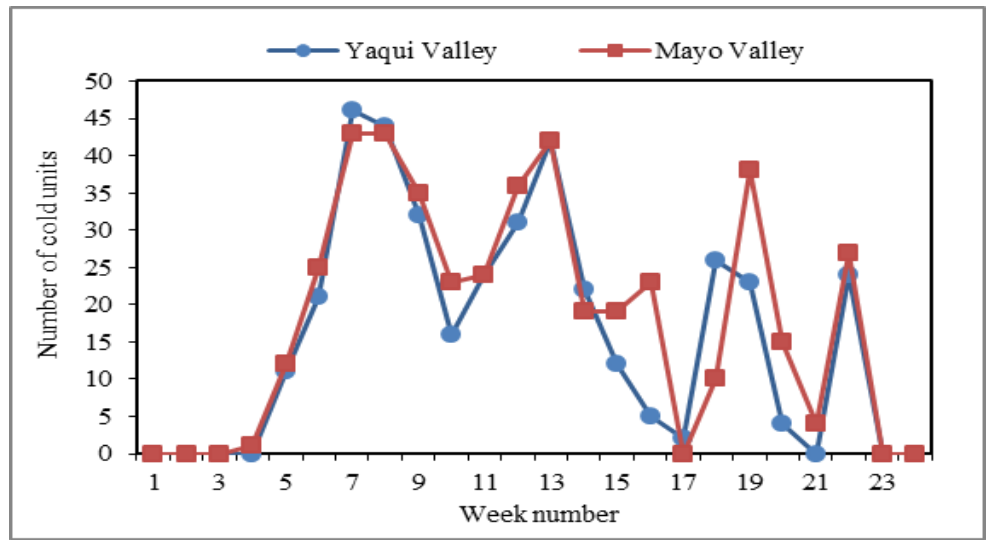

Figure 3. Cold units accumulated per week in the Yaqui and Mayo Valleys during the wheat season 2019-2020.

The weather stations in the Yaqui Valley with the highest number of cold units were blocks 1730, 609, and Estación Corral with 663, 594, and 563 cold units, respectively (Fig. 4A), while in the Mayo Valley stood out the weather station Capetamaya with 736 cold units, followed by Tres Carlos and La Regla with 503 and 500, respectively (Fig. 4B). The weather stations with the lowest number of cold units in the Yaqui Valley were block 419 and 1423 with 297 and 209 cold units, respectively, and in the Mayo Valley the stations Pueblo Mayo and Juliantabampo with 341 and 277 , respectively.

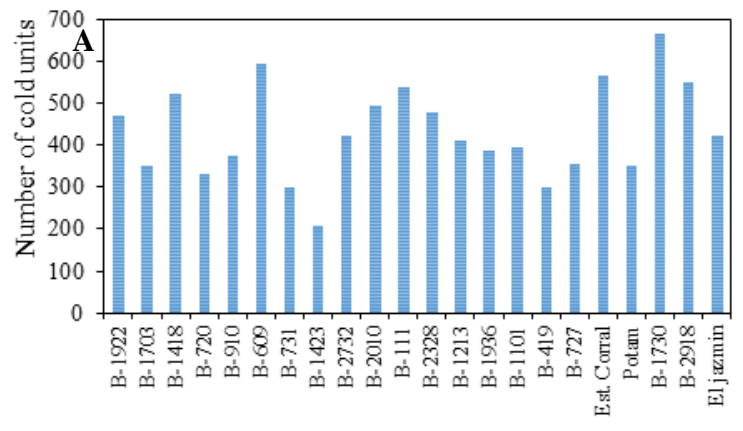

Weather stations in the Yaqui Valley

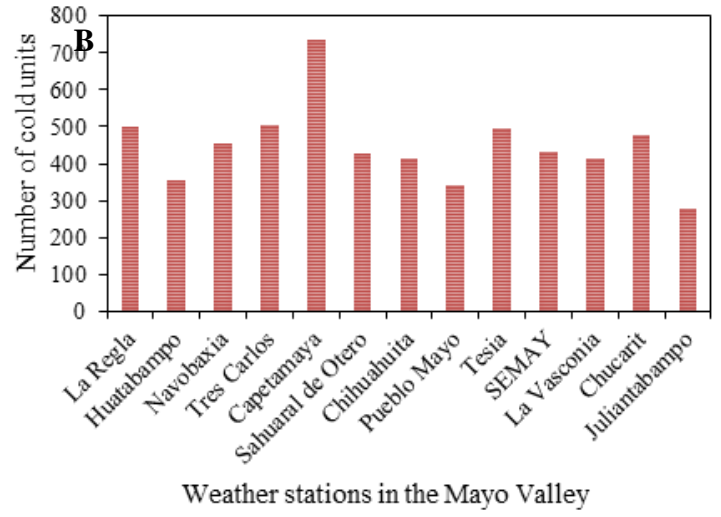

Weather stations in the Mayo Valley

Figure 4. Cold units recorded in each weather station from the Yaqui (A) and Mayo (B) Valleys, during the wheat season 2019-2020. 
However, there were heat waves or sudden temperature rise during the initial to intermedium phase of grain formation, which generally occurs during the month of March (Fig. 5). This factor and the limitation of water for irrigation influenced a reduction of grain yield, as it was the case of the Mayo Valley where the average grain yield obtained was $6.18 \mathrm{t} \mathrm{ha}^{-1}$, lower than the yield obtained in the Yaqui Valley (6.89) (SIAP, 2021), despite the greater number of cold units in the Mayo Valley.

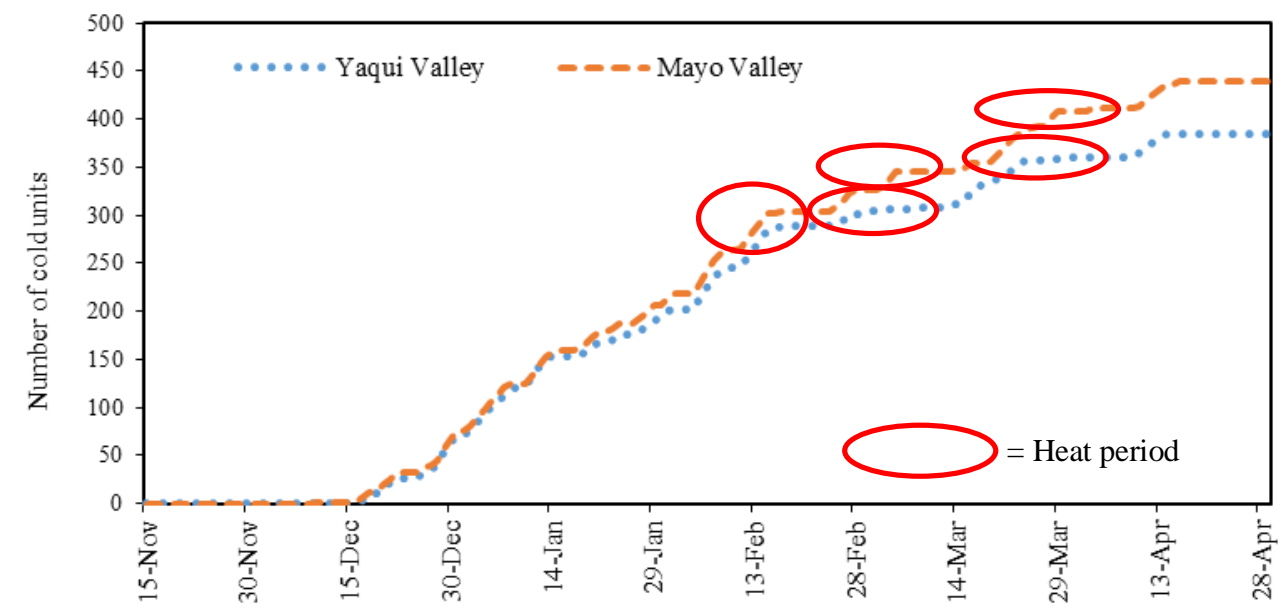

Figure 5. Heat waves in the Yaqui and Mayo Valleys during the wheat season 2019-2020.

The effect of high temperature during most of the grain filling period, with moderate temperature $\left(<32^{\circ} \mathrm{C}\right)$ for a long time or during short periods with high temperature $\left(>35^{\circ} \mathrm{C}\right)$, causes a reduction in grain yield which can reach up to 35\% (Shpiler and Blum, 1986; Ishag and Mohamed, 1996; Tahir and Nakata, 2005; Wardlaw and Wrigley, 1994; Tewolde et al., 2006). High temperatures have a complex effect on crops which in turn will affect negatively yield and quality. The occurrence of such temperatures depend on factors like sowing date and altitude, among others.

\section{CONCLUSION}

During the crop season 2019-2020, the temperature in the Yaqui and Mayo Valleys was rather similar oscillating between $1.4^{\circ} \mathrm{C}$ and $35.6^{\circ} \mathrm{C}$ with an average of $17.8^{\circ} \mathrm{C}$; an average of 385 and 439 cold units were recorded in the Yaqui and Mayo Valleys, respectively. Most of the weather stations in the Mayo Valley had a similar pattern of cold unit occurrence, which were aroun 400, with the exception of Capetamaya which had more than 700 cold units. In the Yaqui Valley, there were six stations with around 400 cold units, five with more than 500, and only one with more than 600 .

\section{REFERENCES}

Félix-Valencia P, Ortíz-Enríquez JE, Fuentes-Dávila G, Quintana-Quiróz JG y Grageda-Grageda J. 2009. Horas frío en relación al rendimiento de trigo: áreas de producción del estado de Sonora. INIFAP, Centro de Investigación Regional del Noroeste, Campo Experimental Valle del Yaqui. Folleto Técnico No. 63. Cd. Obregón, Sonora, México. 40 p. 
Vol. 06, No. 04; 2021

ISSN: $2456-8643$

Fuentes-Dávila G, Torres-Cruz MM, Félix-Valencia P, Valdenebro-Esquer B, Castelo-Muñoz G, and Félix-Fuentes JL. 2019. Presence of wheat stripe rust in southern Sonora during the 2018-19 crop season. Annual Wheat Newsletter 65:35-39.

Ishag HM, Mohamed BA. 1996. Phasic development of spring wheat and stability of yield and its components in hot environments. Field Crops Res. 46:169-176.

Lira Ibarra M. 1992. Karnal bunt (Tilletia indica) of wheat in the state of Sonora, Mexico. pp. 69. In: Update on Karnal Bunt Research in Mexico. Wheat Special Report No. 7. Eds. FuentesDavila, G., and Hettel, G.P. CIMMYT. Cd. Obregon, Sonora, Mexico. May 8-9, 1991. Pages 138.

Márquez Berber SR, Almaguer Vargas G, Rindermann Schwentesius R, y Ayala Garay AV. 2014. Trigo en Sonora y su contexto nacional e internacional. http://biblioteca.diputados.gob.mx/janium/bv/cedrssa/lxii/trig soncon nacint.pdf. Accessed on May 25, 2021

Moreno Dena JM, Salazar Solano V, Rojas Rodríguez IS. 2018. Impactos económicos de las horas frío en la producción de trigo en Sonora, México. Entreciencias: Diálogos en la Sociedad del Conocimiento 6(16):17-31.

Padilla Valenzuela I, Valenzuela Valenzuela RI, Armenta Castro CM, Salinas Pérez RA, y Sánchez Sánchez E. 2008. Comportamiento agronómico de genotipos de garbanzo en siembra tardía en el Valle del Mayo, Sonora, México. Revista Fitotecnia Mexicana 31(1):43-49.

Parra-Cota FI, Coronel-Acosta CB, Amézquita-Avilés CF, De los Santos-Villalobos S, y Escalante-Martínez DI. 2018. Diversidad metabólica de microorganismos edáficos asociados al cultivo de maíz en el Valle del Yaqui, Sonora. Revista Mexicana de Ciencias Agrícolas 9(2):431442. doi: 10.29312/remexca.v9i2.1083.

REMAS (Red de Estaciones Metereológicas Automáticas de Sonora). 2021. Descargar datos. http://www.siafeson.com/remas/. Accessed on May 15, 2021.

Servicio de Información Agroalimentaria y Pesquera (SIAP). 2021. Avance de siembras y cosechas. Resumen nacional por estado. Trigo grano. Ciclo otoño-invierno. Riego + temporal. Disponible en: https://nube.siap.gob.mx/cierreagricola/. Accessed on May 20, 2021.

Shpiler L, Blum A. 1986. Differential reaction of wheat cultivars to hot environments. Euphytica 35:483-492.

Singh RP, Huerta-Espino J, Pfeiffer W, and Figueroa-Lopez P. 2004. Occurrence and impact of a new leaf rust race on durum wheat in northwestern Mexico from 2001 to 2003. Plant Dis. 88(7):703-708. doi: 10.1094/PDIS.2004.88.7.703.

Soto F, Plana R, Hernández N. 2009. Influencia de la temperatura en la duración de las fases fenológicas del trigo harinero (Triticum aestivum sp. aestivum) y triticale (X Triticum secale Wittmack) y su relación con el rendimiento. Cultivos Tropicales 30(3):32-36.

Tahir ISA, Nakata N. 2005. Remobilization of nitrogen and carbohydrate from stems of bread wheat in re-sponse to heat stress during grain filling. Journal of Agronomy and Crop Science 191:105-116.

Tewolde H, Fernandez CJ, Erickson CA. 2006. Wheat cultivars adapted to post-heading high temperature stress. Journal of Agronomy and Crop Science 192:111-120.

Wardlaw IF, Wrigley CW. 1994. Heat tolerance in temperate cereals: an overview. Australian Journal of Plant Physiology 21:695-703. 